удк 343.9:355.4](477)

DOI https://doi.org/10.32837/yuv.v0i4.2231

\author{
Б. Луценко, \\ аспірант \\ Харківського національного університету внутрішніх справ
}

\title{
КРИМІНОЛОГІЧНИЙ АНАЛІЗ ПІДСТАВ ПРОВЕДЕННЯ ОПЕРАЦІЇ ОБ'ЄДНАНИХ СИЛ
}

Постановка проблеми. Загальновідомо, що кожна дія є результатом причини, що їй передувала і водночас причиною наступної дії. Цьому безперервному ланцюжку причин і дій підкоряються всі процеси буття. Що стосується підстав проведення Операціï об'єднаних сил (ООС), то повне ї розуміння і необхідність можливе за умов аналізу причин початку діяльності Антитерористичної операції (ATO).

Безумовно, такі події не $є$ результатом однієї причини. Такі причини не сьогоденні, а доволі системні і тривалі; вони лежать на поверхні та серед них можна виділити такі: нерівномірний соціальний та економічний розвиток окремих регіонів, відмінність у політичних курсах, різниця в культурних цінностях, гострі протиріччя у питаннях історіі. Проте каталізатором цих довготривалих системних причин стали події, що розгорнулися на майдані у Києві наприкінці листопада 2013 року, після відмови Президентом В. Януковичем підписати угоду про асоціацію з Європейським Союзом. Подальша зміна влади у Києві спричинила неоднозначне сприйняття в окремих територіях України, що призвело до виникнення перших конфліктів.

Стан літератури. Науковою спільнотою приділяється значна увага подіям, що відбуваються на сході України. Дослідниками і практичними працівниками з економіки, соціології, політології, військової сфери, громадських організацій, міжнародної спільноти, фахівцями з адміністративного та кримінального права, кримінологами здійснений вагомий внесок у вивчення ситуаціі, що склалася, 3 метою недопущення ескалації конфлікту та відновлення всіх законних прав держави Україна та їі громадян.

Мета дослідження - кримінологічний аналіз підстав, які передували прийняттю рішення про проведення ATO та подальше переформатування ATO в OOC.

Виклад основного матеріалу. Передумовами подій у східних і південних територіях України стали анексія Кримського півострова та вуличні акціі на підтримку Митного союзу в Києві. Провокації на початку березня у Києві були незначними, правоохоронцям вдавалося контролювати ситуацію. Проте акції протесту у квітні заполонили східну територію з новою силою.

6 квітня 2014 року терористи захопили будівлі обласних державних адміністрацій у Донецьку та Харкові, а в Луганську - управління СБУ, де зберігалася значна кількість стрілецької зброї. Уже 7 квітня 2014 року контрольовані, керовані та фінансовані російськими спецслужбами колаборанти проголосили створення так званих «ДНР» і «Харківської народної республіки», а в Луганську створили «штаб Південно-Східного спротиву» та висунули вимоги щодо виходу східних регіонів зі складу України (створення «ЛНР» було проголошено 27 квітня). Одночасно спостерігалися спроби російських 
спецслужб дестабілізувати обстановку в Запорізькій, Миколаївській, Херсонській, Одеській і Дніпропетровській областях [1, с. 20].

Донецька і Луганська області, на відміну від інших, залишилися у полі зору незаконних збройних формувань. За даними групи «Інформаційний спротив», станом на 9 квітня 2014 року кількість російських диверсійних і терористичних утворень перевищувала 2500 осіб [2, с. 16]. На зазначених територіях незаконні збройні формування (терористичні групи) здійснювали такі правопорушення, як «напади на прикордонні підрозділи, захоплювали відділки міліції та СБУ, транспортні засоби, об'єкти банківської системи та засобів масової інформації, блокували військові об'єкти, шантажували місцеве населення, захоплювали заручників і вчиняли умисні вбивства» [1, с. 21].

Надалі ситуація ще погіршилася, і вже 12 квітня незаконні збройні формування одночасно захопили м. Слов'янськ, міську раду м. Артемівськ та м. Краматорськ.

Того ж дня в Горлівці була вчинена невдала спроба збройного захоплення міськради. Проте вже 14 квітня 2014 року терористичній групі під керівництвом російського офіцера вдалося встановити контроль над Горлівським міським відділком міліціi. У Луганську 11 квітня 2014 року російські терористичні групи так званого «об'єднаного штабу армії Південного Сходу» взяли в облогу Луганську обласну раду та поставили ультиматум про невизнання центральної влади в Україні і проголошення «ЛНР». За їхньої участі до кінця квітня 2014 року на території багатьох населених пунктів Донецької і Луганської областей бойовики захопили десятки об'єктів державної інфраструктури, вчинили збройні напади на підрозділи й частини українських силових структур. Зокрема, були захоплені державні установи у містах Зугрес, Іловайськ, Макіївка, Маріу- поль, Харцизьк, Костянтинівка, Єнакієве та блоковані військові частини НГ України в Маріуполі та Луганську, дві бази зберігання озброєння і військової техніки поблизу міста Артемівськ. Окрім того, були вчинені спроби отруєння особового складу військових підрозділів через їжу та воду, теракти з викрадення людей, зокрема військовослужбовців, захоплення озброєння і військової техніки [1, с. 22-23].

3 огляду на події, що відбувались у постмайданній Україні, а також на процеси у східних і південних регіонах країни, керівництво держави змушено було вжити заходів щодо забезпечення національної безпеки та захисту життя і здоров'я громадян України від таких загроз, як зміна конституційного ладу України; порушення і обмеження у здійсненні конституційних прав і свобод людини і громадянина, а також прав і законних інтересів юридичних осіб; захоплення державних установ; обмеження у здійсненні державної політики органами державної влади України; незаконне втручання у діяльність органів місцевого самоврядування; неможливість відповідного забезпечення в економічній, соціальній, безпековій, правоохоронній, оздоровчій, культурній та інших сферах на окремих територіях.

Реакцією держави на такі виклики було рішення РНБО України від 13 квітня 2014 року «Про невідкладні заходи щодо подолання терористичної загрози і збереження територіальної цілісності України». Законом України «Про боротьбу 3 тероризмом» (ухвалено 2003 р., чинний у редакції від 5 червня 2014 р.) визначено антитерористичну операцію як «комплекс скоординованих спеціальних заходів, спрямованих на попередження, запобігання і припинення терористичної діяльності, звільнення заручників, забезпечення безпеки населення, знешкодження терористів, мінімізацію наслідків терористичної діяльності» [3]. 
Цим самим законом зазначено, що терористична діяльність - це діяльність, яка охоплює такі дії: планування, організацію, підготовку та реалізацію терористичних актів; підбурювання до вчинення терористичних актів, насильства над фізичними особами або організаціями, знищення матеріальних об'єктів у терористичних цілях; організацію незаконних збройних формувань, злочинних угруповань (злочинних організацій), організованих злочинних груп для вчинення терористичних актів, так само, як і участь у таких актах; вербування, озброєння, підготовку та використання терористів; пропаганду й поширення ідеології тероризму; фінансування та інше сприяння тероризму.

Проведення АТO спочатку відповідало тогочасним загрозам, проте подальші події червня-липня 2014 р., за даними Моніторингової місії ООН з прав людини в Україні, свідчать про «професіоналізацію збройних груп, які воюють на сході: те, що раніше було «різношерстим збіговиськом озброєних людей із різними переконаннями і цілями», нині об'єднується під централізованим командуванням. Тепер вони застосовують важке озброєння, а саме: міномети і зенітні гармати, танки, броньовані машини й наземні міни» [4].

За даними MBC, лише з 1 серпня до 26 жовтня 2014 р. було відкрито понад 300 кримінальних проваджень щодо артилерійських обстрілів населених районів Донецької області, які здійснювалися без дотримання принципу розрізнення. 4 жовтня 2014 р. Військова прокуратура східного регіону ініціювала перше кримінальне провадження за звинуваченням у тероризмі через артилерійські обстріли населених районів м. Дебальцеве [5, с. 10].

Фахівці британського аналітичного центру «Королівський інститут об'єднаних служб» підготували спеціальну доповідь, де зазначалося про масштабну участь російської армії у боях з українськими підрозділами від середини серпня 2014 р. Чисельність армії оцінювалася в межах від 3,5 тис. до 6-6,5 тис. у кінці літа, а в середині грудня минулого року на піку прямого російського втручання вона досягла чисельності приблизно 10 тис. осіб [6, с. 4].

Особливо кричуща ситуація склалася на окупованих територіях, де траплялися численні випадки умисних убивств та позасудових страт, позбавлення особистої свободи та викрадення людей, катування, пограбування населення, інші злочини, пов'язані з окупацією регіону державою-агресором. Ці злочини вчинялися як учасниками незаконних збройних формувань із числа місцевого населення та найманців із Росіі, так і особами з числа професійних російських військових і представників спецслужб цієї держави, представлених у регіоні. Сплеск злочинності не оминув і підконтрольну уряду України територію. Найбільшу кількість злочинів тут було вчинено у період розпалу конфлікту (2014-2015 рр.). Східноукраїнський центр громадських ініціатив та інші правозахисні організації фіксували в цей період окремі факти вбивств, численні насильницькі зникнення, порушення недоторканості та пограбування житла цивільного населення в районах ведення бойових дій $[7$, с. 8].

У доповіді офісу комісара $\mathrm{OOH}$ 3 прав людини зазначалося, що з середини квітня 2014 до 15 лютого 2015 рр. на території двох східних областей загинуло щонайменше 5665 людей (включаючи 298 осіб, які перебували на борту малайзійського літака «Боїнг-777», що виконував регулярний рейс $\mathrm{MH}-17$ за маршрутом Амстердам - Куала-Лумпур), 13961 осіб зазнали поранень різного ступеня тяжкості [8].

За даними слідчого управління ГУ НП у Донецькій області за період із 01.04 .2014 p. до 30.06 .2018 p. 
з приміткою «Правопорушення, пов’язане з проведенням антитерористичної операції», відбувалися кримінальні правопорушення, такі як умисні вбивства, тілесні ушкодження різного ступеню тяжкості, побої та мордування, катування, незаконне позбавлення волі або викрадення людей, порушення недоторканості житла, крадіжки, грабіж, розбій, шахрайство, умисне знищення або пошкодження майна; сприяння учасникам злочинних організацій та укриття їхньої злочинної діяльності; терористичний акт; створення терористичної групи чи терористичної організації; фінансування тероризму; створення не передбачених законом воєнізованих або збройних формувань; незаконне поводження зі зброєю, бойовими припасами або вибуховими речовинами; незаконне заволодіння транспортним засобом; захоплення державних або громадських будівель чи споруд; самоправство; самовільне залишення військової частини або місця служби.

Частина зазначених злочинів порушує не тільки національне законодавство, але й Конвенцію про захист цивільного населення під час війни від 12 серпня 1949 р. та Римський статут міжнародного кримінального суду від 17 квітня 1998 р., якими передбачені злочини проти людяності та воєнні злочини.

На підтвердження цього свідчить Звіт щодо діяльності з попереднього вивчення за 2020 рік прокурора Міжнародного кримінального суду Фату Бенсуда, опублікований 14 грудня 2020 року, який містить таку інформацію щодо подій на сході України: пп. 227-281 - можливе вчинення воєнних злочинів; використовується посилання на пункти статті 8 Римського статуту про воєнні злочини, які стосуються як міжнародного, так і неміжнародного збройного конфлікту. Стосовно подій на Донбасі Oфic Прокурора MKC вважає, що у цьому регіоні могли (можуть) вчинятися такі воєнні злочини: навмисне спрямування нападів проти цивільних осіб і цивільних об'єктів; навмисне спрямування нападів проти захищених будівель; умисне вбивство, катування або таке, що принижує гідність людини/жорстоке відношення; приниження людської гідності; згвалтування та інші форми сексуального насильства. Крім того, Офіс Прокурора MKC вважає, що, якщо на Донбасі існує один міжнародний збройний конфлікт, то додатково там могли (можуть) вчинятися такі воєнні злочини: навмисне спрямування нападів, що спричинили шкоду цивільним особам і цивільним об'єктам, які явно перевищували передбачену військову перевагу (непропорційні напади); незаконне затримання [9].

Усвідомлюючи характер подій на сході України та наслідки, що настали і можуть настати, Верховна Рада України звернулася до Організації Об’єднаних Націй, Європейського парламенту, парламентської асамблеї Ради Європи, НАТО, ОБСЕ, ГУАМ i національних парламентів країн світу про визнання Російської Федерації державою-агресором (27 січня 2015 р.), а також із заявою Верховної Ради України щодо відсічі збройній arресії Російської Федерації та подолання їі наслідків (21 квітня 2015 р.). В обох документах абсолютно коректно $з$ погляду на міжнародне право стосовно російських дій використовується саме термін «агресія». У заяві прямо відзначається: «Силові дії Російської Федерації, що тривають із 20 лютого 2014 року, є актами збройної агресії відповідно до пунктів "а", "b", “c", "d" та "g" статті 3 резолюціï 3314 (XXIX) Генеральної Асамблеї ООН "Визначення агресії" від 14 грудня 1974 р.» [10, с. 179].

На законодавчому рівні термін «агресія» використаний у Законі України «Про особливості державної політики із забезпечення державного суверенітету України на тимчасово окупованих територіях у Донецькій та Луганській областях» 
від 18.01.2018 № 2268-VIII як «збройна агресія», «злочини агресії». Цим законом визначені такі грубі порушення принципів і норм міжнародного права, як систематичне недодержання режиму припинення вогню та продовження обстрілів цивільних об'єктів та інфраструктури, що спричиняють численні жертви серед цивільного населення, військовослужбовців Збройних Сил України та інших утворених відповідно до законів України військових формувань; продовження практики протиправного затримання й утримання громадян України на тимчасово окупованих територіях, їхнього незаконного вивезення та утримання на території Російської Федерації; намагання поширити російське законодавство, зокрема податкове, на територіях окремих районів Донецької та Луганської областей, висування незаконних вимог щодо перереєстрації підприємств і стягнення коштів на користь окупаційної адміністрації Російської Федерації в окремих районах Донецької і Луганської областей; запровадження російського рубля як єдиної валюти на території окремих районів Донецької і Луганської областей; свавільне застосування російських освітніх стандартів у навчальних закладах; запровадження на підприємствах в окремих районах Донецької і Луганської областей «зовнішнього управління» і визнання незаконних ідентифікаційних документів та реєстраційних знаків транспортних засобів на території окремих районів Донецької і Луганської областей; організація і здійснення насильницьких зникнень, катувань, нелюдського поводження або покарання, позасудових страт цивільного населення, українських військовослужбовців і заручників» [11].

Беручи до уваги все зазначене вище, цілком логічним $є$ рішення керівництва держави про переформатування АТО в ООС, оскільки ефективно протидіяти зазначеним злочинам і можливим загрозам, керуючись тільки Законом України «Про боротьбу з тероризмом», неможливо. Новий формат діяльності на сході України передбачає досить широкі можливості використання сил і засобів задля забезпечення національної безпеки та оборони, відсічі і стримування збройної агресії Російської Федерації.

Окремо варто наголосити, що, хоча наше національне законодавство не закріплює термін «гібридна війна», проте події на сході України дуже часто називають саме гібридною війною. Водночас аналітичною доповіддю «Проект багатьох варіантів майбутнього: Орієнтування до 2030 р.» ( «Multiple Futures Project: Navigating Toward 2030»), підготовленою 2009 р. під егідою НАТО, особливо гострі загрози для країн-учасниць альянсу очікуються саме від «гібридних форм війни, коли конвенційні, іррегулярні та кримінальні потенціали поєднуються оперативно й тактично на найнижчому рівні в міському середовищі» [12].

За визначенням члена верхньої палати парламенту Нідерландів генерал-майора у відставці Ф. ван Каппена, «це є мішаниною класичного ведення війни з використанням нерегулярних збройних формувань. Держава, яка веде гібридну війну, укладає оборудку 3 недержавними виконавцями - бойовиками, групами місцевого населення, організаціями, зв'язок з якими формально повністю заперечується. Ці виконавці можуть робити такі речі, які сама держава робити не може, тому що будь-яка держава зобов'язана дотримуватися Женевської конвенції та Гаазької конвенції про закони сухопутної війни, домовленості з іншими країнами. Всю брудну роботу можна перекласти на плечі недержавних формувань» [13].

Висновки. Резюмуючи наведене вище, можна зазначити, що з погляду на кримінологічний аналіз наша держава не була готова до подій на сході 
України. Відсутність аналізу проблем, причинно-наслідкових зв'язків, прогнозування можливих наслідків, рекомендацій щодо своєчасних дій відповідних суб'єктів на відміну від досліджень, проведених на замовлення НАТО вже у 2004 та 2009 роках у сфері міжнародної безпеки, є цьому підтвердження. Вся діяльність на сході країни, починаючи з 2014 року, - це діяльність навздогін, проте аналіз і висновки - це вже постфактум. За таких умов досить складно досягти мети й виконання задач, що стоять перед ATO та OOC. Проте за умов відсутності теоретичних досліджень і практичного досвіду Україна дотримується уникнення ескалації конфлікту, збереження людського життя, недопущення дестабілізації у східному регіоні.

Загалом проведення АТO i OOC $€$ відповідною реакцією на подіiі, що відбулися на сході України, проте важливо розуміти й ефективно працювати на випередження за допомогою кримінологічних заходів.

Статтю присвячено дослідженню подій, що передували рішенню про початок Aнтитерористичної операції, а в подальшому - Oперації об'єднаних сил. Подіï, щзо відбулись у південних $i$ східних областях України, потребують саме кримінологічного аналізу, оскільки саме в такий спосіб можна приймати ефективні управлінські рішення.

Підставами прийняття рішення про початок Антитерористичної операції на сході України стали численні правопорушення, передбачені не тільки національним, але й міннародним законодавством. Відомості про безпрецедентні порушення прав $і$ свобод людини та посягання на територіальну цілісність України підтверджені не тільки офіційною владою України, але й рядом громадських організацій, а також міжнародними орга- нізаціями (Організація Об’єднаних Націй, Міжнародний кримінальний суд, Парламентська асамблея Ради Esponu).

Переформатування Aнтитерористичної операції в Операцуію об'єднаних сил з кримінологічної точки зору мало на меті розширення суб'єктного складу задля забезпечення національної безпеки та оборони, відсічі, стримування збройної агресії Російської Федераияї у Донещькій $i$ Луганській областях, а також наділення цих суб'єктів спеціальними повноваженнями. Зміна формату була необхідною реакцією на подіï $i$ наслідки, щзо настали у період з 2014 до 2018 рр., які вже далеко вийшли за межі терористичної діяльності.

Проте варто зауважити, щзо нашій країні за відсутності теоретичних напрацювань і практичного досвіду протистояння збройним конфліктам доволі складно діяти в цій ситуаиіï на випередження. Кримінологічне забезпечення $i$ супроводження Операції об'єднаних сил надасть можливість системно $i$ своєчасно з урахуванням набутого досвіду та міжнародної практики досягти поставлених иүілей із забезпечення державного суверенітету, відновлення територіальної цілісноcmi, захисту прав і свобод людей та законних інтересів юридичних осіб.

Ключові слова: кримінологічний аналіз, Антитерористична операція, Операція об’єднаних сил.

Lutsenko B. Criminological analysis of the grounds for conducting the Joint Forces Operation

The article is focused on studying the events that preceded the decision to adopt the Anti-Terrorist Operation, and later the Joint Forces Operation. The events that took place in the Southern and Eastern regions of Ukraine require criminological analysis, because it is the correct way to make effective management decisions. 
Numerous offenses of both national and international law were the reasons for the decision to launch the Anti-Terrorist Operation on the East of Ukraine. Data on unprecedented violations of human rights and freedoms and encroachment on the territorial integrity of Ukraine has been confirmed not only by the official authorities of Ukraine, but also by a number of public and international organizations (United Nations, International Criminal Court, Parliamentary Assembly of the Council of Europe).

According to the criminological point of view the reformatting of the Anti-Terrorist Operation into the Joint Forces Operation was aimed at expanding the parties in order to ensure national security and defense, to repel and deter the armed aggression of the Russian Federation in Donetsk and Luhansk regions, as well as to provide these subjects with special powers. The change in format was a necessary reaction to the events and consequences that occurred in the period from 2014 to 2018, which had already gone far beyond terrorist activities.

However, it should be noted that it is quite difficult for our country to act preventively in this situation, when there is lack of theoretical and practical experience in counteracting armed conflicts. Criminological provision and support of the Joint Forces Operation will provide an opportunity to systematically and in a timely manner, taking into account the obtained experience and international practice, to achieve the set goals of state sovereignty, restoration of territorial integrity, protection of human rights and freedoms, as well as legitimate interests of legal entities.

Key words: criminological analysis, Anti-Terrorist Operation, Joint Forces Operation.

\section{Література}

1. Біла книга антитерористичної операції на Сході України (2014-2016) / під заг. ред. I. Руснака. Київ: Національний університет оборони України імені Івана Черняховського, 2017. 162 с.

2. Гусаров В., Карин Ю., Машовец, К., Тымчук Д. Вторжение в Украину: хроника российской агрессии. Киев : Брайт Стар Паблишине, 2016. 240 c.

3. Про боротьбу з тероризмом : Закон України від 20.03.2003 № 638-IV. База даних «Законодавство України»/ BP України. URL: https: / / zakon.rada.gov. ua/laws/show/638-15\#Text (Jama звеpнення: 15.08.2021).

4. Доповідь щодо ситуації з правами людини в Україні 15 листопада 2014 p. URL: https: / / www.ohchr.org / en/ countries / enacaregion/ pages / uareports. aspx (дата звернення: 15.08.2021).

5. Збройний конфлікт на сході Украіни: шкода, завдана житлу цивільного населення / упоряд. Н. М. Мельник. Харків : ТОВ «Видавництво "Права людини"», 2019. 86 c.

6. Sutyagin I. Russian Forces in Ukraine. Royal United Services Institute: Briefing Paper. 2015. March, P. 4. URL: http: / / mepoforum.sk / wp-content / uploads/2015/03/Russian-Forces-inUkraine-RUSI.pdf (дата звернення: 16.08.2021).

7. Одегов О., Гриценко Н. Злочини без покарання: порушення прав людини під час збройного конфлікту на сході України. Київ, 2018. 64 с.

8. Report on the Human Rights Situation in Ukraine: 1 December 2014 to 15 February 2015. URL: http://www.ohchr.org/ Documents / Countries / UA/9thOHCHRreportUkraine.pdf (дата звернення: 16.08.2021).

9. Кориневич А. Про Звіт Офісу Прокурора Міжнародного кримінального суду щодо діяльності з попереднього вивчення за 2020 рік. Українська правда. URL: https: / / www.pravda.com.ua/ columns/2020/12/15/7277010/ (Jama звернення: 18.08.2021).

10. Головко В. В. Україна в умовах антитерористичної операції ma російської збройної атресії $(2014$ р.) Український історичний журнал. 2015. № 3. С. 176-193.

11.Про особливості державної політики із забезпечення державного суверенітету України на тимчасово 


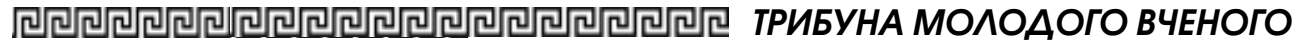

окупованих територіях у Донецькій та Луганській областях : Закон України від 18.01.2018 № 2268-VIII. База даних «Законодавство України»/ ВР України. URL: https://zakon.rada.gov.ua/laws / show/2268-19\#Text (даma звернення: 14.08.2021)

12. Multiple Futures Project: Navigating Toward 2030. April, 2009. P. 41. URL: https: / / www.act.nato.int / images / stories / events / 2009 / m fp / 20090503_ MFP_finalrep.pdf (дата звернення: 10.08.2021)

13. Корнієнко С. Путін веде в Україні гібридну війну - генерал Kanпен. Радіо Свобода. URL: http: / / www.radiosvoboda.org / content/article/25363591.html (Jama звернення: 10.08.2021). 